\title{
The Intensity of Tomato Post-Harvest Rot in the Surroundings of Tandojam
}

\author{
Safia Nizamani ${ }^{1, a}$, Allah Jurio Khaskheli ${ }^{2, b}$, Asad Ali Khaskheli ${ }^{3, c}$, Absar Mithal Jiskani ${ }^{4, d}$, \\ Sajad Ali Khaskheli ${ }^{4, \mathrm{e}}$, Gul Bahar Poussio ${ }^{\text {,f, }}$, Hafeez-u-Rahman Jamro ${ }^{1, \mathrm{~g}}$, Muhammad Ibrahim Khaskheli1 ${ }^{1, \mathrm{~h}, *}$ \\ ${ }^{1}$ Department of Plant Protection, Sindh Agriculture University, Tandojam-70051 Pakistan \\ ${ }^{2}$ Department of Biotechnology, Sindh Agriculture University, Tandojam-70051 Pakistan \\ ${ }^{3}$ Department of Animal Nutrition, Sindh Agriculture University, Tandojam-70051 Pakistan \\ ${ }^{4}$ Department of Plant Pathology, Sindh Agriculture University, Tandojam-70051 Pakistan \\ ${ }^{5}$ Plant Pathology Section, Agriculture Research Centre, Tandojam-70051 Pakistan \\ *Corresponding author
}

\section{A R T I C L E I N F A B S T R A C T}

Research Article

Tandojam is one of the main tomatoes producing city in Pakistan. Several tones of tomatoes are produced in the Tandojam each year. The main objective of the study was to estimate the intensity of tomato post-harvest rot in the vicinity of Tandjam, so curative strategies can be explored. A survey was conducted in the surrounding of Tandojam viz; Tando Allahyar, Sultanabad Vegetable

Received : 06/08/2020

Accepted : 27/01/2021 Market, Tandojam city, Tando Qaiser, Bahawal Zaur, and Hyderabad Vegetable Market. A total of 20 tomato growers/farmers, 30 brokers, and 23 small shopkeepers were interviewed based on the proforma developed in the current study. The fruit rot infection among all 20 different fields ranged from 5 to $65 \%$ with $31.85 \%$ infected fruits by Alternaria. At Sultanabad and Hyderabad vegetable markets infection was ranged from 20 to $60 \%$ and 10 to $70 \%$, respectively, with mean percentages 37 and $38.5 \%$ infected by Alternaria sp. Infection in small shops was ranged from 16.67 to $60 \%$ in

Keywords: Alternaria rot Tandojam city and 16.67 to $53.33 \%$ in Tando Qaiser. The overall comparison revealed 30 percent Intensity Post-harvest loss Target places infected fruit by Alternaria under field conditions, 36 percent at the vegetable market, and 43 percent at small shops level. Controlling tomato rots is a big challenge as the intensity of this disease is unknown in different regions. This research has significantly contributed to estimating the Tomato intensity of this disease.

safia.nizamani@yahoo.com c@khaskhelias@gmail.com esalikhaskheli@gmail.com g@hafeezjamro@yahoo.com

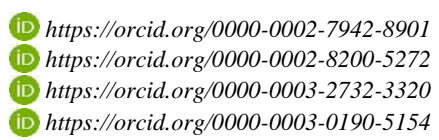

(i) https://orcid.org/0000-0002-7942-8901
(iD) https://orcid.org/0000-0002-8200-5272
(i) https://orcid.org/0000-0003-2732-3320
(i) https://orcid.org/0000-0003-0190-5154

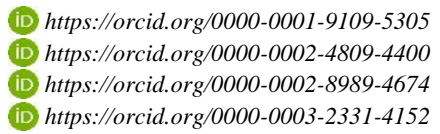

(c) (1) () This work is licensed under Creative Commons Attribution 4.0 International License

\section{Introduction}

Tomato and several tomato-based products are an important source of many established nutrients and phytochemicals though have several health benefits. Several products of tomato are being used in our daily life such as sun-dried, juice, soup, sauce, ketchup, and unsullied as a salad (Nazli et al., 2006). It is more frequently used as a source of daily diet vegetable, consumed raw as well as cooked, and is used as soups, salads, preserves, pickles, sauces, and many other products. It is a rich source of several important macro and micronutrients including carbohydrates, proteins, fats, minerals, and vitamins (Talvas et al., 2010). People have realized the importance of tomatoes to be a healthy diet because tomatoes are known to contain many compounds that play an important role in the prevention of cancer, heart disease, cataracts, and many other common health problems (Olaleye et al., 2014).

In Pakistan, climatic conditions are very conducive that favor the good quality production of tomatoes round a year. Pakistan annually produces two crops; first in spring and second in autumn. However, it can be grown throughout the year in the southern part of Pakistan. In Pakistan, tomato is grown on an area of 1680 and 38549 hectares with an average production of 142114 and 423930 tonnes during Kharif (summer) and Rabi (winter) seasons, respectively. Sindh province contributes a major proportion of tomato production (202386 Tonnes) followed by Punjab (94549 Tonnes) and KPK (31552 Tonnes), particularly in Rabi 
season (GOP, 2016). Besides the nutritional and economic importance of tomatoes, several biotic and abiotic factors are responsible for the decline in yield. The yield of tomatoes is also affected by many pathogenic diseases every year. The world over reported diseases of tomato are about 59, including 17 viral, 28 fungal, 4 bacterial, 3 plants parasitic nematode, and 4 miscellaneous diseases or disorders (Jones et al., 1993). Among these, the common fungal diseases are damping-off of seedlings and wilt of the adult crop (Fusarium oxysporum f. sp. lycopersici, Rhizoctonia solani, Pythium spp. and Verticillium albo-atrum) and fruit rot (Alternaria tenuis). These diseases are responsible to deteriorate quantity and quality of the product and the yield losses are reported from 30 to $100 \%$ in tropical regions (Pandey et al., 2017). Opportunistic pathogens which generally cause fruit rots diseases are such kinds of microorganisms though survive on the debris of plant. Such microorganisms can infect wounded and/or exposed tissues that do not have a protective surface. These microbes are normally good saprophytes that can be found everywhere in nature. At the time of harvesting and different handling stages unintentionally several cuts and punctures (mechanical injuries) are occurring, which are the initial and frequent sites for post-harvest rot development on the fruit surface. Inconsistently, those that have entered deeply in tissues below the surface of fruit (internalized pathogens) also cause inside rots in the fruit (Charchar et al., 2003). Moreover, certain fungi can colonize the damaged tissues due to internal bruises occurred during harvest, and ultimately producing black rot. Normally, the lesions that are quickly developing are a major cause of texture loss progress until the fruit collapse (soft rots). The structures and materials are produced during lesion development and progression that can cause rot to other nearby adjacent fruits, leading to a nest of infection. Post-harvest handling, weak storage practices, transportation, and improper marketing are the major contributing factors for fruit rot disease in tomatoes (Rani and Khetarpaul, 2009).

Alternaria species have been a major plant pathogens world nowadays. It causes at least $20 \%$ of agricultural spoilage, while severe losses may reach up to $80 \%$ of yield. It affects the leaves, stems, flowers, and fruits. This pathogen severely damages tomato production by causing a disease namely tomato fruit rot (Nowicki et al., 2012). Tomato post-harvest rot is becoming a major threat in Pakistan including all provinces and cities. The control of tomato fruit rots is going to be a big challenge for researchers as the intensity of this disease is still known in different regions of Pakistan. Under such situations, it is impossible to implement preventive and curative strategies against this threatening disease. The present research was therefore organized to focus on the main tomato producing city of Pakistan, whereby the key objective was to estimate the intensity of tomato fruit rot disease for the formulation of future research and integrated tomato fruit rot management strategies.

\section{Materials and Methods}

\section{Study Location}

The present study was conducted in the laboratories of the Department of Plant Protection, Sindh Agriculture University, Tandojam, Pakistan, and surrounding tomato fields, local shops, and big markets.

\section{Estimation of Tomato Post-Harvest Rot}

Survey for tomato post-harvest rot was conducted from February to April 2017 in the surrounding of Tandojam viz; Tando Allahyar, Sultanabad Vegetable Market, Tandojam city, Tando Qaiser, Bahawal Zaur, and Hyderabad Vegetable Market to estimate the tomato postharvest rots.

A total of 20 tomato growers/farmers from different fields, 30 brokers from vegetable markets, and 23 small shopkeepers were interviewed based on the proforma developed in the current study. A comprehensive set of questionnaires was developed to record the interviews of the selected respondents. The questionnaire comprised the queries about tomato fruit rot losses, production, and marketing (Table 1). Primary data were collected which included the field, market, and shops for fruit post-harvest losses. Farmers, brokers, and shopkeepers were interviewed using a structured questionnaire with open and closed questions. The questions sought to obtain information on production, grading, sale, and post-harvest losses. To estimate the percent fruit rot caused by fungi, a total of 20 fruits from each farmer's field, 10 from each broker of the vegetable market, and all available injured/rotted samples from each small shopkeeper were randomly observed based on the visual symptoms produced by fruit rot causing fungi. The disease intensity (Percentage of infected fruit: PIF) was calculated by using the formula of diseases incidence as under:

$$
\mathrm{PIF}=\frac{\text { Number of Infected Fruits }}{\text { Total Number of Observed Fruits }} \times 100
$$

Laboratory Confirmation of Post-Harvest Tomato Rot

Random samples were collected from the fields, markets, and small shops and brought to the laboratory, department of Plant Protection. The collected samples were washed with tap water and small pieces of infected portion were cut. Pieces were surface sterilized in $0.1 \%$ mercuric chloride solution for 30 seconds and then washed with sterilized distilled water thrice. After drying the sample pieces, five bits were transferred aseptically to the Petri-dishes containing sterile potato dextrose agar (PDA) medium amended with an antibacterial agent and filled up to quarter strength. The inoculated plates were incubated at $25 \pm 20^{\circ} \mathrm{C}$. The culture, thus, obtained was subjected to purification. A single spore culture technique was used to purify the isolates. Further, slides of fungal isolates from pure cultures were made and observed under a light microscope. Morphological and cultural characters of isolated fungi were recorded and compared with standard keys for establishing their identity (Barnett and Hunter, 1972; Nelson et al., 1983).

\section{Statistical Analysis}

The data obtained in present were statistically analysed by using the standard procedures for analysis of variance, ANOVA (linear model), and mean separation (least significant difference, LSD) of all parameters including frequency $(\%)$, fruit infection (\%) (after calculating with corresponding formulas) were analysed by using the computer software Statistics 8.1 (Analytical Software, 2005). All differences described in the text were significant at the $5 \%$ level of probability. Some data were analysed using MS Excel Programme of MS Office 2007. 
Table 1. The questionnaire used for the collection of information and further analysis of data for tomato fruit

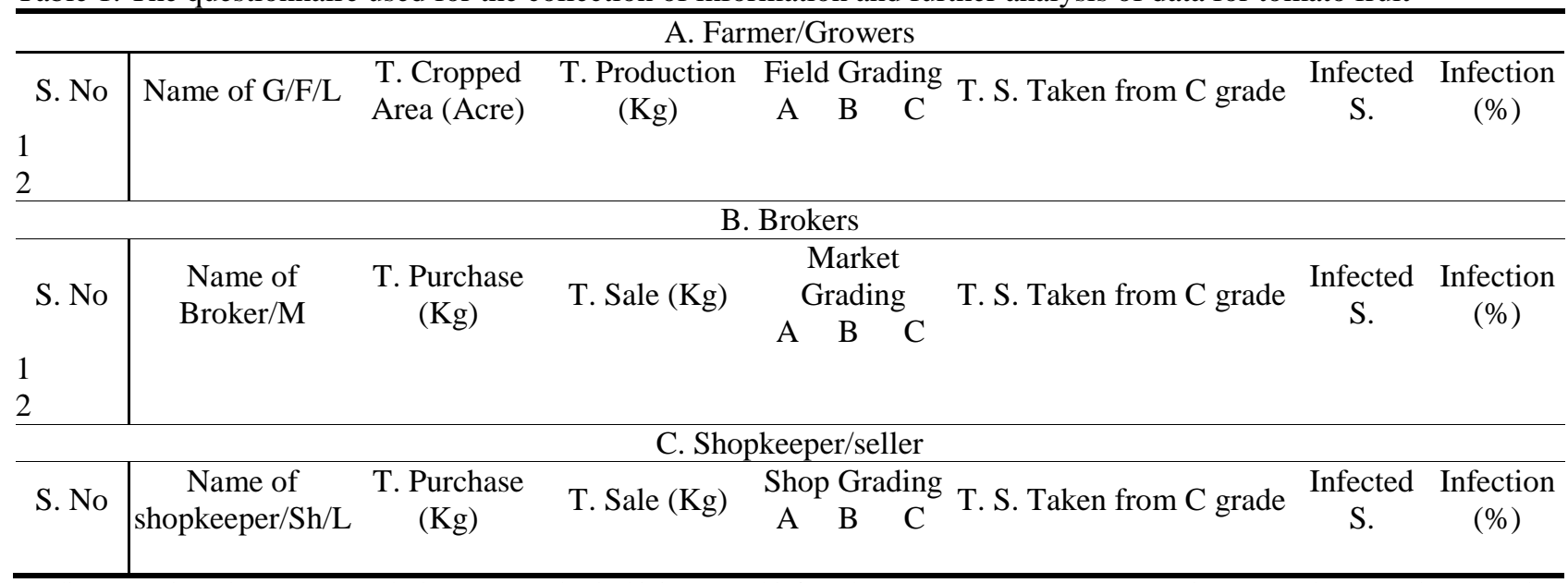

Grading: A = First Class; B = Second Class; C = Mechanical injury/rotted/infected, G: Grower, F: Farmer, L: Location, T: Total, S: Sample, M: Market, Sh: Shop

Table 2. Information taken based on the questionnaire from different tomato growers/farmers under field conditions

\begin{tabular}{|c|c|c|c|c|c|c|}
\hline \multirow[t]{2}{*}{ S. No } & \multirow[t]{2}{*}{ Location/ Grower } & \multirow[t]{2}{*}{ Total Cropped Area (Acre) } & \multirow[t]{2}{*}{ Total Production (Kg) } & \multicolumn{3}{|c|}{ Field Grading } \\
\hline & & & & A & $\mathrm{B}$ & $\mathrm{C}$ \\
\hline 1 & Sadam & 5.5 & 12800 & 9600 & 3200 & 192 \\
\hline 2 & Moonwar & 3 & 9120 & 8640 & 480 & 48 \\
\hline 3 & Sobhat & 3 & 9280 & 8320 & 960 & 80 \\
\hline 4 & Alidino & 2 & 8320 & 7360 & 960 & 64 \\
\hline 5 & Ata Muhammad & 2.5 & 6400 & 5920 & 480 & 32 \\
\hline 6 & Shebair & 2.5 & 7520 & 6960 & 560 & 40 \\
\hline 7 & Muhammad Khan & 2.5 & 6480 & 5920 & 560 & 32 \\
\hline 8 & Ali Hassan & 5 & 9600 & 9120 & 480 & 32 \\
\hline 9 & Mujeeb & 3 & 7200 & 6960 & 240 & 16 \\
\hline 10 & Irfan & 3 & 6544 & 6224 & 320 & 16 \\
\hline 11 & Majeed & 6 & 14432 & 9664 & 4768 & 288 \\
\hline 12 & Muneer & 3.5 & 8928 & 8416 & 512 & 32 \\
\hline 13 & Abbas & 1.5 & 4448 & 4320 & 128 & 16 \\
\hline 14 & Shahnawaz & 1.5 & 3200 & 3040 & 160 & 16 \\
\hline 15 & Hakeem & 1.5 & 4224 & 4000 & 224 & 16 \\
\hline 16 & Ghalum Shah & 4.5 & 8080 & 7840 & 240 & 16 \\
\hline 17 & Shokat & 5 & 9728 & 9328 & 400 & 16 \\
\hline 18 & Saleem & 4 & 5056 & 4768 & 288 & 16 \\
\hline 19 & Rasheed & 3 & 6416 & 6080 & 336 & 32 \\
\hline 20 & Abid & 3.5 & 8368 & 7808 & 560 & 32 \\
\hline \multicolumn{2}{|l|}{ Total } & 66 & 156144 & 140288 & 15856 & 1032 \\
\hline \multicolumn{2}{|l|}{ Mean } & 3.3 & 7807.2 & 7014.4 & 792.8 & 51.6 \\
\hline \multicolumn{2}{|c|}{ Per Acre } & 1.1 & 2602.4 & 2338.13 & 264.266 & 17.2 \\
\hline \multicolumn{2}{|c|}{ SE } & 0.298 & 611.65 & 436.26 & 255.5 & 15.317 \\
\hline
\end{tabular}

\section{Results}

The estimation of post-harvest losses of tomato fruits was calculated based on the interviews conducted through open and close questions structured in the questionnaire of the current study. The data collected from 20 different farmers/growers of the Tando Allahyar region indicates the total mean production of about $2602.4 \mathrm{Kg}$ per 1.1 acres as per their verbal discussion. They also categorized their products into different field grades based on the quality of tomatoes like size, colour, and mechanical injuries or diseases. About $2338.133 \mathrm{Kg}$ tomato were graded superior as A categories and $264.2667 \mathrm{Kg}$ into B grade category out 2602.4 Kg per 1.1 acres (mean of 20 farmers) as per the requirement of the commercial market. Whereas, about 17.2 $\mathrm{Kg}$ tomato fruits per 1.1 acre were spoilt due to mechanical injury during harvesting, insect pest problems, physiological disorders, and fruit rot problems sorted after harvesting (Table 2).

The estimation of post-harvest losses of tomato fruits was calculated from Sultanabad and Hyderabad vegetable markets based on the interviews conducted through open and closed questions structured in the questionnaire of the current study. The recorded from 30 brokers for tomato fruit rot losses, total purchase, and sale per day, market grading showed great variation among different brokers. In Sultanabad vegetable market, a total purchase per day by one broker was $148.8 \mathrm{Kg}$ (mean of 10 brokers) and per day sale was $140.8 \mathrm{Kg}$. When they were asked for market grading, as per their verbal discussion, a total of $72 \mathrm{Kg}$ was 
separated as A grade and $14.4 \mathrm{Kg}$ as $\mathrm{B}$ grad tomato fruits (mean of 10 brokers). They also responded for post-harvest losses due to mechanical injury during transportation, physiological disorders, and fruit rot problems for about $22.4 \mathrm{Kg}$ per day. It was also noticed that some brokers were selling without any grading and sorting (Figure 1; Table 3). Similarly, in the Hyderabad vegetable market, a total purchase and sale per day by one broker has recorded 310.4 and $255.2 \mathrm{Kg}$ (mean of 20 brokers), respectively. For market grading, $261.33 \mathrm{Kg}$ were separated as A grade and $50.667 \mathrm{Kg}$ as B grad tomato fruits (mean of 20 brokers). The post-harvest losses due to mechanical injury during transportation, physiological disorders, and fruit rot problems as per their verbal feedback; $23.11 \mathrm{Kg}$ per day was recorded. Similar to Sultanabad, some brokers were selling without any grading and sorting in the Hyderabad vegetable market (Table 3 ).

The response of 23 small shopkeepers interviewed based on the proforma developed in the current study also showed great differences among all noticed parameters. In Tandojam city, a total purchase per day by one shopkeeper has recorded $124.8 \mathrm{Kg}$ (mean of 10 brokers) and per day sale noticed was $98.8 \mathrm{Kg}$. When they were asked for tomato grading, as per their verbal discussion, a total of $65.2 \mathrm{Kg}$ was separated as A grade and $22.1 \mathrm{Kg}$ as B grad tomato fruits (mean of 10 brokers) in their shops. They also responded for post-harvest losses due to mechanical injury during transportation, physiological disorders, and fruit rot problems for about 14.3 $\mathrm{Kg}$ per day. It was also noticed that some shopkeepers were selling without any grading and sorting of tomato fruits in their shops (Table 4). Similarly, in Tando Qaiser, a total purchase and sale per day by one shopkeeper were recorded 56 and $39.3 \mathrm{Kg}$ (mean of 10 Shopkeepers), respectively. For tomato grading at the shop, $22.4 \mathrm{Kg}$ were separated as $\mathrm{A}$ grade and $7.4 \mathrm{Kg}$ as $\mathrm{B}$ grad tomato fruits (mean of 20 brokers). The post-harvest losses due to mechanical injury during transportation, physiological disorders, and fruit rot problems as per their verbal feedback; $07 \mathrm{Kg}$ per day was recorded. Similar to Tandojam, some shopkeepers were selling without any grading and sorting in Tando Qaiser (Table 4).

Table 3. Information taken based on the questionnaire from different tomato brokers in commercial markets

\begin{tabular}{|c|c|c|c|c|c|c|}
\hline \multirow{2}{*}{ S. No } & \multirow{2}{*}{ Market/ Broker } & \multirow{2}{*}{ Total Purchase (Kg/Day) } & \multirow{2}{*}{ Total Sale (Kg/Day) } & \multicolumn{3}{|c|}{ Market Grading } \\
\hline & & & & A & $\mathrm{B}$ & $\mathrm{C}$ \\
\hline \multicolumn{7}{|c|}{ Sultanabad Vegetable Market ( 28-2-2017) } \\
\hline 1 & Raza Ali & 208 & 192 & 160 & 32 & 16 \\
\hline 2 & Mansokah & 160 & 144 & 128 & 32 & 32 \\
\hline 3 & Gewan Das & 128 & 128 & \multicolumn{2}{|c|}{ Mixed } & 16 \\
\hline 4 & Ashok Kumar & 160 & 144 & \multicolumn{2}{|c|}{ Mixed } & 16 \\
\hline 5 & Terath Raj & 128 & 128 & \multicolumn{2}{|c|}{ Mixed } & 16 \\
\hline 6 & Lukhy & 80 & 80 & 64 & 16 & 16 \\
\hline 7 & Wasiu & 64 & 64 & 48 & 16 & 16 \\
\hline 8 & Irfan Ahmed & 192 & 176 & 144 & 16 & 32 \\
\hline 9 & Gulab & 128 & 128 & \multicolumn{2}{|c|}{ Mixed } & 16 \\
\hline \multirow[t]{4}{*}{10} & Altaf & 240 & 224 & 176 & 32 & 48 \\
\hline & Total & 1488 & 1408 & 720 & 144 & 224 \\
\hline & Mean & 148.8 & 140.8 & 72 & 14.4 & 22.4 \\
\hline & $\mathrm{SE}$ & 17.37 & 15.235 & 21.367 & 3.5777 & 3.5377 \\
\hline \multicolumn{7}{|c|}{ Hyderabad Vegetable Market ( 02-03-2017) } \\
\hline 1 & M. Afzal & 480 & 416 & 352 & 80 & 48 \\
\hline 2 & Sardar & 192 & 176 & \multicolumn{2}{|c|}{ Mixed } & \\
\hline 3 & Noor Muhammad & 288 & 256 & 192 & 64 & 32 \\
\hline 4 & Naeem & 192 & 160 & 176 & 16 & 0 \\
\hline 5 & Vakram & 320 & 240 & \multicolumn{2}{|c|}{ Mixed } & \\
\hline 6 & Wanood & 224 & 176 & 192 & 16 & 16 \\
\hline 7 & Iftikhar & 160 & 128 & 128 & 16 & 16 \\
\hline 8 & Shankar & 400 & 320 & 304 & 48 & 48 \\
\hline 9 & Manthar & 480 & 400 & \multicolumn{2}{|c|}{ Mixed } & 0 \\
\hline 10 & Barkat & 192 & 144 & \multicolumn{2}{|c|}{ Mixed } & 0 \\
\hline 11 & Asghar & 480 & 368 & 272 & 112 & 96 \\
\hline 12 & Ali Muhammad & 400 & 336 & 304 & 64 & 48 \\
\hline 13 & Papoo & 240 & 144 & \multicolumn{2}{|c|}{ Mixed } & 0 \\
\hline 14 & Haji Ramzan & 400 & 368 & 336 & 48 & 16 \\
\hline 15 & Ali Ahmed & 160 & 160 & \multicolumn{2}{|c|}{ Mixed } & 0 \\
\hline 16 & Faheem & 240 & 192 & \multicolumn{2}{|c|}{ Mixed } & 0 \\
\hline 17 & Imran & 400 & 400 & 320 & 32 & 48 \\
\hline 18 & Iqbal & 432 & 288 & 320 & 80 & 32 \\
\hline 19 & Noor Ali & 240 & 208 & \multicolumn{2}{|c|}{ Mixed } & 0 \\
\hline 20 & Mujtaba & 288 & 224 & 240 & 32 & 16 \\
\hline \multirow{3}{*}{\multicolumn{2}{|c|}{$\begin{array}{l}\text { Total } \\
\text { Mean } \\
\text { SE }\end{array}$}} & 6208 & 5104 & 3136 & 608 & 416 \\
\hline & & 310.4 & 255.20 & 261.33 & 50.67 & 23.11 \\
\hline & & 25.34 & 22.008 & 21.24 & 8.77 & 6.23 \\
\hline
\end{tabular}


Table 4. Information is taken based on the questionnaire from different tomato seller/shopkeeper in the bazaar

\begin{tabular}{|c|c|c|c|c|c|c|}
\hline \multirow{2}{*}{$\begin{array}{c}\text { S. } \\
\text { No }\end{array}$} & \multirow{2}{*}{ Location/ Shopkeeper } & \multirow{2}{*}{$\begin{array}{c}\text { Total Purchase } \\
\text { (Kg/Day) }\end{array}$} & \multirow{2}{*}{$\begin{array}{l}\text { Total Sale } \\
\text { (Kg/Day) }\end{array}$} & \multicolumn{3}{|c|}{ Market Grading (Kg) } \\
\hline & & & & $\mathrm{A}$ & $\mathrm{B}$ & $\mathrm{C}$ \\
\hline \multicolumn{7}{|c|}{ Tandojam (30-1-2017) } \\
\hline 1 & Arshad & 32 & 24 & 20 & 8 & 4 \\
\hline 2 & Aslam & 32 & 21 & 22 & 6 & 4 \\
\hline 3 & Janie & 64 & 46 & 40 & 14 & 10 \\
\hline 4 & Ahmed Ali & 128 & 112 & 80 & 33 & 15 \\
\hline 5 & Aamir & 96 & 80 & 70 & 14 & 12 \\
\hline 6 & Abdul Aziz & 144 & 120 & 100 & 24 & 20 \\
\hline 7 & Aziz & 80 & 65 & 50 & 7 & 8 \\
\hline 8 & Shokat & 96 & 70 & \multicolumn{2}{|c|}{ Mixed } & 10 \\
\hline 9 & Muhammad Usman & 320 & 265 & 160 & 65 & 40 \\
\hline 10 & Ali Muhammad & 256 & 185 & 110 & 50 & 20 \\
\hline & Total & 1248 & 988 & 652 & 221 & 143 \\
\hline & Mean & 124.8 & 98.8 & 65.2 & 22.1 & 14.3 \\
\hline & SE & 29.867 & 24.138 & 15.253 & 6.9764 & 3.3667 \\
\hline \multicolumn{7}{|c|}{ Bahawal Zaur (03-02-2017) } \\
\hline 1 & Ashfaque Ali & 32 & 20 & 18 & 9 & 5 \\
\hline 2 & Azim & 16 & 10 & 9 & 5 & 2 \\
\hline 3 & Aziz & 48 & 30 & 30 & 10 & 8 \\
\hline & Total & 96 & 60 & 57 & 24 & 15 \\
\hline & Mean & 32 & 20 & 19 & 8 & 5 \\
\hline & SE & 9.2376 & 5.7735 & 6.0828 & 1.5275 & 1.7321 \\
\hline \multicolumn{7}{|c|}{ Tando Qaiser (29-1-2017) } \\
\hline 1 & Roshan Khaskheli & 48 & 30 & 30 & 8 & 10 \\
\hline 2 & Ashfaq Nizamani & 80 & 65 & 50 & 15 & 15 \\
\hline 3 & Fateh Ali Dhamach & 32 & 24 & 24 & 6 & 2 \\
\hline 4 & \multicolumn{2}{|l|}{ Ashfaq Nizamani (Kharo Khoh) } & 48 & 40 & 10 & 14 \\
\hline 5 & \multicolumn{2}{|l|}{ Sheeral Khore } & 48 & 45 & 20 & 15 \\
\hline 6 & \multicolumn{2}{|l|}{ Ghulam Nabi Lohar } & 45 & Mix & 0 & 0 \\
\hline 7 & \multicolumn{2}{|l|}{ Hanif Nizamani } & 65 & Mix & 0 & 0 \\
\hline 8 & \multicolumn{2}{|l|}{ Abdul Majeed } & 40 & 35 & 15 & 14 \\
\hline 9 & \multicolumn{2}{|l|}{ Rasheed Nizamani } & 20 & Mix & 0 & 0 \\
\hline 10 & & 16 & 8 & $\operatorname{mix}$ & 0 & 0 \\
\hline \multicolumn{2}{|r|}{$\begin{array}{l}\text { Shanjan } \\
\text { Total }\end{array}$} & 560 & 393 & 224 & 74 & 70 \\
\hline & Mean & 56 & 39.3 & 22.4 & 7.4 & 7 \\
\hline & SE & 8 & 5.9424 & 3.9299 & 2.3627 & 2.2509 \\
\hline
\end{tabular}

The response of shopkeepers in Bahawal Zaur also remained almost the same as to Tandojam and Tando Qaiser. A total purchase and sale per day by one shopkeeper have recorded 32 and $20 \mathrm{Kg}$ (mean of 03 Shopkeepers), respectively. For tomato grading at the shop, $19 \mathrm{Kg}$ were separated as A grade and $8 \mathrm{Kg}$ as B grad tomato fruits (mean of 03 shopkeepers). The post-harvest losses due to mechanical injury during transportation, physiological disorders, and fruit rot problems as per their verbal feedback; $05 \mathrm{Kg}$ per day was recorded (Table 4).

\section{Alternaria Post-Harvest Tomato Fruit Rot Intensity}

Survey for tomato post-harvest fruit rot caused by Alternaria sp. conducted in the surrounding of Tandojam viz; farmer's field in Tando Allahyar, Sultanabad and Hyderabad vegetable markets, small shops of Tandojam city, Tando Qaiser and Bahawal Zaur showed great variability. The percent of infected fruits by Alternaria in 20 different farmer/grower's fields is presented in Figure 2. The fruit rot infection noticed among all 20 different fields was ranged from 5 to $65 \%$. However, the mean percent of infected fruits by Alternaria for all 20 farmers/grower's fields was recorded at $31.85 \%$ (Figure 2).
The percent of infected fruits by Alternaria in Sultanabad and Hyderabad vegetable markets also showed the variation (Figure 3 and 4). The fruit rot infection noticed in both vegetable markets, Sultanabad and Hyderabad; was ranged from 20 to $60 \%$ and 10 to $70 \%$, respectively. However, the mean percent of infected fruits by Alternaria for Sultanabad and Hyderabad vegetable markets were recorded 37 and $38.5 \%$, The results regarding the percent of infected fruits by Alternaria in small shops of Tandojam, Tando Qaiser, and Bahawal Zaur is presented in Figure 5. The fruit rot infection was ranged from 16.67 to $60 \%$ in Tandojam city, whereas in Tando Qaiser it was ranged from 16.67 to $53.33 \%$, respectively. However, the mean percent of infected fruits by Alternaria in both Tandojam and Tando Qaiser shops were recorded 36.187 and $35.46 \%$, respectively (Figure 5). On overall basis farmer fields, vegetable markets, and small shops were also compared for percent of post-harvest fruit rot of tomato. The result revealed 30 percent infected fruit by Alternaria under field conditions, 36 percent at the vegetable market, and 43 percent at small shops level (Figure 6). 


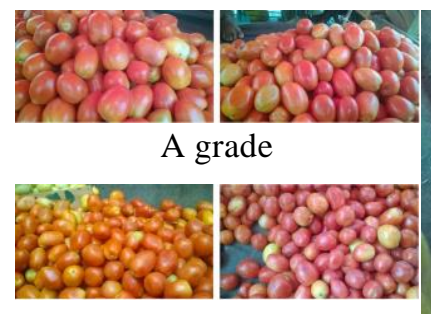

B grade
$\mathrm{C}$ grade

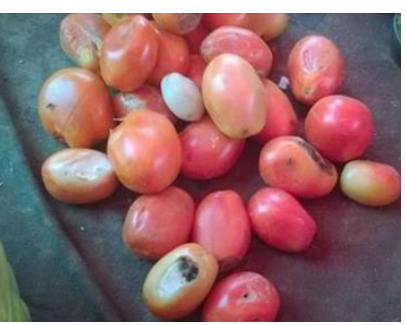

Figure 1. Different grading of tomato-based on the quality of tomato

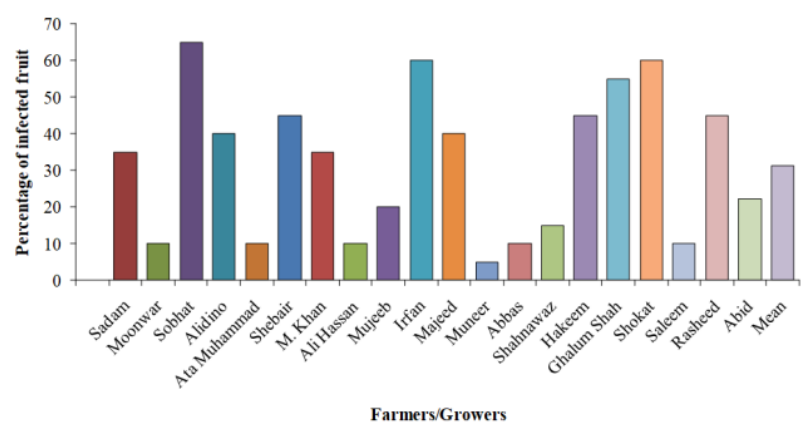

Figure 2. Percentage of fruit infected with Alternaria rot observed under field conditions $\mathrm{SE}=4.4487, \mathrm{LSD}(\mathrm{P}<0.05)=0.0000$

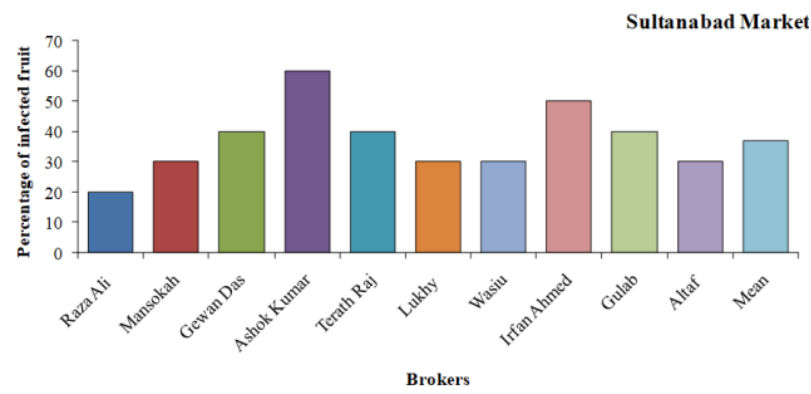

Figure 3. Percentage of fruit infected with Alternaria rot observed under the vegetable market of Sultanabad. $\mathrm{SE}=4.0000, \mathrm{LSD}(\mathrm{P}<0.05)=0.0001$

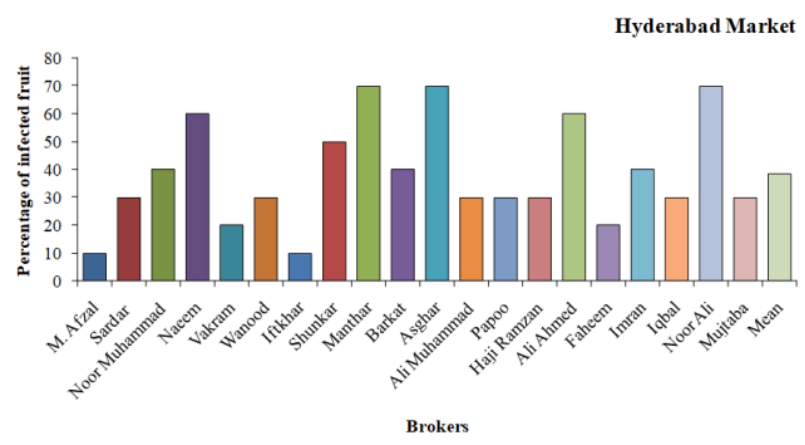

Figure 4. Percentage of fruit infected with Alternaria rot observed under the vegetable market of Hyderabad. $\mathrm{SE}=4.1295, \mathrm{LSD}(\mathrm{P}<0.05)=0.0000$

\section{Discussion}

Tomato is a highly perishable crop and more than $50 \%$ of these produces are lost between productions to consumption (Oyeniran, 1988). The main reasons for postharvest losses are external damages that occurred during harvesting and handling, improper harvesting at the maturity stage, and then decaying (Thorne and Alvarez, 1982). The current research was conducted to estimate the intensity of tomato post-harvest rot in the surroundings of Tandojam to plan future research work and integrated tomato fruit into management strategies. Moreover, postharvest handling, weak storage practices, transportation, and improper marketing are seriously affecting the quality of tomatoes. It has been reported that any change in the availability, edibility, wholesomeness, or quality of food that prevents it from being eaten by man is known as the post-harvest loss (Mbuk et al., 2011). In the current study, a survey for tomato post-harvest losses and fruit rot was conducted. The estimation of post-harvest losses of tomato fruits was calculated based on the interviews conducted through open and close questions structured in the questionnaire of the current study.

The data collected from 20 different farmers/growers of the Tando Allahyar region indicates the total mean production of about $2602.4 \mathrm{Kg}$ per 1.1 acres as per their verbal discussion. They also categorized their products into different field grades based on the quality of tomatoes like size, color, and mechanical injuries or diseases. About $2338.133 \mathrm{Kg}$ tomato were graded superior as A categories and $264.2667 \mathrm{Kg}$ into B grade category out $2602.4 \mathrm{Kg}$ per 1.1 acres (mean of 20 famers) as per the requirement of the commercial market. Whereas, about $17.2 \mathrm{Kg}$ tomato fruits per 1.1 acre were spoilt due to mechanical injury during harvesting, insect pest problems, physiological disorders, and fruit rot problems sorted after harvesting. The data recorded from 30 brokers for tomato fruit rot losses, total purchase, and sale per day, market grading showed great variation among different brokers. In the Sultanabad vegetable market, post-harvest losses due to mechanical injury during transportation, physiological disorders, and fruit rot problems for about $22.4 \mathrm{Kg}$ per day.

Similarly, in the Hyderabad vegetable market, a total purchase and sale per day by one broker has recorded 310.4 and $255.2 \mathrm{Kg}$ (mean of 20 brokers), respectively. For market grading, $261.33 \mathrm{Kg}$ were separated as A grade and $50.667 \mathrm{Kg}$ as B grad tomato fruits (mean of 20 brokers). The post-harvest losses due to mechanical injury during transportation, physiological disorders, and fruit rot problems as per their verbal feedback; $23.11 \mathrm{Kg}$ per day was recorded. Similar to Sultanabad, some brokers were selling without any grading and sorting in the Hyderabad vegetable market. The response of 23 small shopkeepers for post-harvest losses due to mechanical injury during transportation, physiological disorders, and fruit rot problems for about $07-14.3 \mathrm{Kg}$ per day, depending upon the consumption of the city. The magnitude of post-harvest losses varies from one country to another, one season to another, and even one day to another (Mujib et al., 2007). It has also been reported that worldwide post-harvest losses are about $25 \%$ or $28-42 \%$, and $15-50 \%$ or $15-60 \%$ in less developed countries. This means that half quantity of food never reaches the consumers.

To reduce post-harvest losses through economical procedures will not only decrease food losses but will also be beneficial for the farmers economically. It is safe to say that post-harvest losses occur in all countries, but the extent of such losses is greater in third world countries (Zaldivar, 1991). 


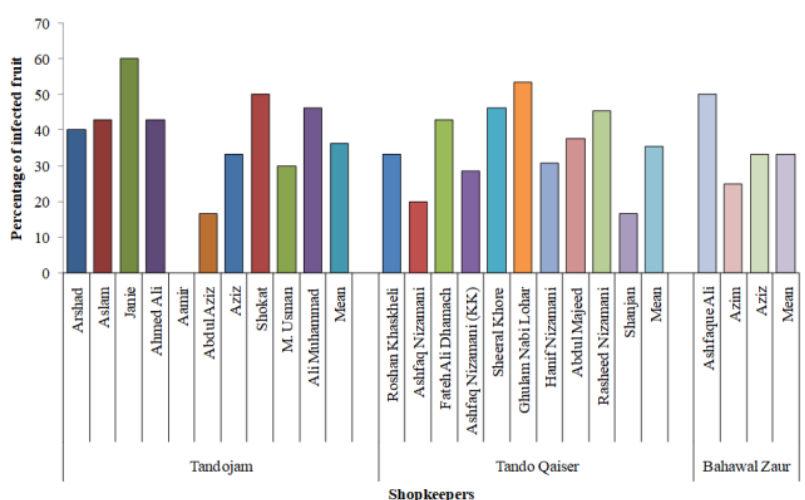

Figure 5. Percentage of fruit infected with Alternaria rot observed under different small shops

$$
\mathrm{SE}=5.4748 \quad 5.7609 \quad 7.3495
$$

$\operatorname{LSD}(\mathrm{P}<0.05)=0.0001 \quad 0.0001 \quad 0.0099$

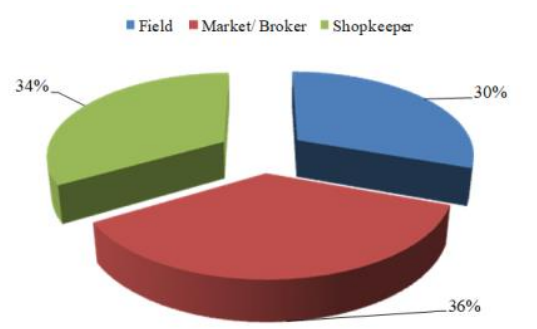

Figure 6. Overall percent infected fruit by Alternaria under field, market and shops level $\mathrm{SE}=1.7004, \mathrm{LSD}(\mathrm{P}<0.05)=0.0024$

Numerous micro-organisms cause post-harvest decay of tomatoes (Obetta et al., 2011). However, tomato fruit rots are mainly caused by fungi such as Geotrichum candidum, Rhizopus stolonifer, black mold rot caused by Alternaria sp., Fusarium rot by Fusarium sp. are more commonly occurring (Burgess et al., 1985; Jofee, 1986; Nelson et al., 1990). Amongst all, Alternaria rot has been considered as the most serious disease of tomato fruits and causes heavy losses in the quality of the fruits, thus rendering a large number of tomato fruits unfit for consumption. Barkai and Fauchs (1980) and Hassan (1996) have reported that Alternaria is the main decay-causing organism of post-harvest tomato fruits while responsible for black rot lesions on tomato fruits. The present study, also calculated the percent of infected fruits by Alternaria in 20 different farmer/grower's fields. The fruit rot infection noticed among all 20 different fields due to Alternaria was ranged from 5 to $65 \%$. However, the mean percent of infected fruits by Alternaria for all 20 farmers/grower's fields was recorded at $31.85 \%$. The fruit rot infection noticed in both vegetable markets, Sultanabad and Hyderabad; was ranged from 20 to $60 \%$ and 10 to $70 \%$, respectively. However, the mean percent of infected fruits by Alternaria for Sultanabad and Hyderabad vegetable markets were recorded 37 and $38.5 \%$, respectively. The fruit rot infection in the small shop was ranged from 16.67 to $60 \%$. However, the mean percent of infected fruits by Alternaria was around 36.187 and $35.46 \%$. On an overall basis 30 percent infected fruit by Alternaria was recorded under field conditions, 36 percent at the vegetable market, and 43 percent at small shops level. The magnitude of postharvest losses always varies from one country to another country and one season to another and even one day to another (Mujib et al., 2007; Sajad, 2017). Our studies are in agreement with Nowicki et al. (2012), who reported that Alternaria species are major plant pathogens, which cause at least $20 \%$ of agricultural spoilage; most severe losses may reach up to $80 \%$ of yield, affecting the leaves, stems, flowers, and fruits. Recently, Sajad et al. (2017) observed that most of the tomato fruits have been suffered from fruit rot disease caused by Alternaria alternata, Aspergillus niger, Geotrichum candidum, Alternaria solani, Mucor racemosus, Aspergillus flavus, Fusarium oxysporum, Fusarium moniliforme, Penicillium digitatum, Rhizopus stolonifer, Alternaria alternata, Colletotrichum lycopersici, Sclerotium rolfsii, Myrothecium roridum, Phoma destructive, and Trichothecium roseum. However, they also reported the maximum percentage frequency (I6.51\%) of occurrences on all tomato fruits for Alternaria alternata. Therefore, control of tomato fruit rots always remained a challenge for researchers not only in Sindh, Pakistan; however, throughout the world.

\section{References}

Barkai GR, Fauchs Y. 1980. Research on post-harvest diseases of tomato. A survey of the organisms causing rot-of stored tomato fruits. Preliminary-report -volcani-centre, Bet-Dagan, 78(2): 1-12.

Barnett HL, Hunter B. 1972. Illustrated genra of imperfect fungi. Burgress publishing company Minneapolis.

Burgess LW, Nelson PE, Tousson TA, Marasas WFO. 1985. Fusarium scirpi: amended description and notes on geographic distribution. Mycologia, 77: 212-218.

Charchar AU, Gonzaga JM, Giordano V, Boiteuy Lde, Reis LS. 2003. Reaction of tomato cultivars to infection by a mixed population of $\mathrm{M}$. incognita race and $\mathrm{M}$. javanica in the field. Nematol Brasileira, 27: 49-54.

GOP, 2016. Agriculture statistics of Pakistan. Govt of Pakistan, Area, production of fruit, vegetables and Condiments. Ministry of Food and Agriculture.

Hassan HAH. 1996. Alternaria mycotoxins in Black rot lesion of tomato fruits: Conditions and regulations of their productions. Acta Immunolgica Hungarica, 43: 125-133.

Joffe AZ. 1986. Fusarium Species: Their Biology and Toxicology. New York: John Wiley and Sons.

Jones JP, Jones JB, Stall RE, Zitter TA. 1993. Common Names of Plant Diseases. Diseases of Tomato (Lycopersicon esculentum Mill.). Retrieved on 08-04-2017; http://www.apsnet.org/ online/common/names/tomato.asp.

Mbuk EM, Bassey NE, Udoh ES, Udoh EJ. 2011. Factors influencing postharvest loss of tomato in Uyo Urban market in Uyo Nigeria. Journal of AgricultureFood Environment, 7(2): 40-46.

Mujib UR, Naushad K, Inayatullah J. 2007. Post-harvest losses of tomato crop. Sarhad Journal of Agriculture, 23(4): 1279-1284.

Mujib UR, Naushad K, Inayatullah J. 2007. Post-harvest losses of tomato crop. Sarhad Journal of Agriculture, 23(4): 1279-1284

Nazli M, Ishaq M, Hussain A, Saddozai KN. 2006. Post-harvest economic losses of tomato crop grown in Peshawar valley. Sarhad Journal of Agriculture, 22(1): 1-6.

Nelson PE, Burgess LW, Summerell BA. 1990. Some morphological and physiological characters of Fusarium species in sections liseola and elegans and similar new species. Mycologia, 82: 99-106.

Nelson PE, Toussoun TA, Marasas WFO. 1983. Fusarium species. An illustrated manual of identification. The State Univ. Press, University Park, Pennslyvania. 
Nowicki M, Nowakowska M, Niezgoda A, Kozik EU. 2012. Alternaria black spot of crucifers: symptoms, importance of disease, and perspectives of resistance breeding vegetable crops. Research Bulletin, 76: 5-19.

Obetta SE, Nwakonobi TU, Adikwu OA. 2011. Microbial effects on selected stored fruits and vegetables under Ambient Makurdi, Benue State, Nigeria. Research Journal of Applied Science, Engineering and Technology, 3(5): 393-398.

Olaleye ON, Omotayo MA, Olanlege AO, Longe AO. 2014 Shelf-Life Extension of Tomato (Lycopersicum esculentum) and Pepper (Capsicum annuum) using aqueous extracts of some Ethnomedicinal plants. Journal of Agricultural Science and Technology, 4: 806-810.

Oyeniran JO. 1988. Reports of the activities of nationally coordinated team on improved packaging and storage of fruits and vegetables in Nigeria. Proceedings of the Workshop on improved packaging and storage systems for fruits and vegetables in Nigeria held in Ilorin, Nigeria.

Pandey AK, Kumar P, Singh P, Tripathi NN, Bajpai VK. 2017. Essential Oils: Sources of Antimicrobials and Food Preservatives. Frontier Microbiology, 7: 2161.
Rani V, Khetarpaul N. 2009. Nutrient composition of tomato products prepared using tomato grown under sodic condition with gypsum and farmyard manure treatment. Journal of Science, Food and Agriculture, 89: 2601-2607.

Sajad AM, Jamaluddin, Abid HQ. 2017. Fungi associated with the spoilage of post-harvest tomato fruits in different markets of Jabalpur, Madhya-Pradesh, India. International Journal of Current Research and Review, 9(5): 12-16.

Talvas J, Caris-veyrat C, Guy L, Rambeau M, Lyan B, MinetQuinard R, Lobaccaro JA, Vasson M, George S, Mazur A, Rock E. 2010. Differential effects of lycopene consumed in tomato paste and lycopene in the form of a purified extract on target genes of cancer prostatic cells. American Journal of Clinical Nutrition, 91(6): 1716-1724.

Thorne S, Alvaremz JSS. 1982. The effect of irregular storage temperature on firmness and surface color in tomatoes. Journal of Science, Food and Agriculture, 33: 671-676.

Zaldivar CP. 1991. Post-harvest losses: significance, assessment and control. In: Memorias Simposio Nacional Fisiologia Tecnologia Postcosecha de Productos Horticolas en Maxico. E.M. Yahia, and I.H. Higuera C. (eds.). Noriega Editores, Mexico. pp. 205-209. 